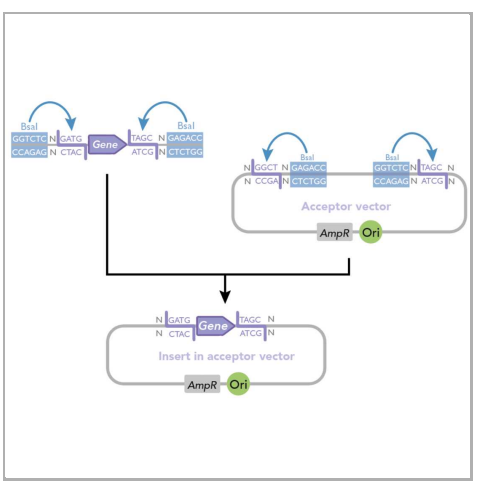

AUG 08, 2021

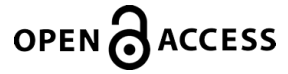

DOI:

dx.doi.org/10.17504/protocol s.io.bkqrkvv6

Protocol Citation: Jamie Auxillos, Edward Wallace 2021. Golden Gate Assembly (Esp31 or Bsal v2 HF). protocols.io

https://dx.doi.org/10.17504/p rotocols.io.bkqrkvv6

License: This is an open access protocol distributed under the terms of the Creative Commons Attribution License, which permits unrestricted use, distribution, and reproduction in any medium, provided the original author and source are credited

Protocol status: Working We use this protocol and it's working

Created: Sep 03, 2020

Last Modified: Aug 08, 2021

PROTOCOL integer ID: 41457

Keywords: Golden Gate, DNA assembly

\section{(3) Golden Gate Assembly (Esp31 or Bsa1 v2 HF)}

Jamie
Auxillos ${ }^{1}$,
Edward Wallace $^{1}$

${ }^{1}$ University of Edinburgh

Wallace lab for Fungal RNA

Tech. support email: Edward.Wallace@ed.ac.uk

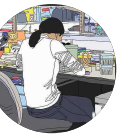

Jamie Auxillos

University of Edinburgh

\section{ABSTRACT}

This protocol is for the assembly of DNA parts using Golden Gate assembly (Engler et al. 2008) with modifications from on publication by Garcia-Ruiz et al. (2018) and online resource by NEB

(https://international.neb.com/protocols/2018/10/02/golden-gate-assemblyprotocol-for-using-neb-golden-gate-assembly-mix-e1601).

Parts can either be assembled by Golden Gate assembly using Esp31 or Bsa1v2-HF depending on the restriction sites flanking the parts. Using this protocol, multiple insert parts can be assembled into the parts acceptor vector. The Golden Gate assembly reaction is incubated in a thermocycling program set at a digestion temperature of at $37^{\circ} \mathrm{C}$ and ligation temperature of $16^{\circ} \mathrm{C}$ for $20-30$ cycles. The reaction is subsequently transformed into $\mathrm{E}$. coli cells (DH5a, Mach1, TOP10, NEB10 $\beta$ ).

1. Engler C, Kandzia R, Marillonnet S (2008)A One Pot, One Step, Precision Cloning Method with High Throughput Capability. PLOS ONE 3(11): e3647. doi:

10.1371/journal.pone.0003647

2. Garcia-Ruiz E, Auxillos J, Li T, Dai J, Cai Y. YeastFab: High-Throughput Genetic Parts Construction, Measurement, and Pathway Engineering in Yeast. Methods Enzymol. 2018;608:277-306. doi: 10.1016/bs.mie.2018.05.003. 


\section{8}

T4 DNA Ligase (2,000,000 units/ml) - 20,000 units New England Biolabs Catalog \#M0202T

Esp3I (BsmBI) $(10 \mathrm{U} / \mu \mathrm{L})$ Thermo Fisher Catalog
\#ER0451

88 Bsal-HFv2 New England Biolabs Catalog \# R3733S

88 Plasmid-Safe ATP-Dependent DNase Lucigen Catalog \#E3101K

PCR-clean (e.g. double-distilled) water

1 Measure the concentration of your insert and vector DNA using a microvolume spectrophotometer (e.g. nanodrop).

Calculate the volumes required to mix equimolar quantities of these. Multiple insert parts can be assembled into the parts acceptor vector.

Note

Tips and Tricks for the insert and vector DNA amounts.

Remember that equimolar quantities means that plasmids or dsDNA of different lengths must be diluted to different concentrations!

For the vector to insert ratio, use the NEBioCalculator

(https://nebiocalculator.neb.com/\#!/ligation) to calculate the volume for a 1:1 insert:vector molar ratio taking into consideration the length of the insert and vector DNA. You can start with a vector amount of between $50-100 \mathrm{ng}$ in $1 \mu$.

Some protocols recommend a 2:1 insert:vector molar ratio. This can help with tricky reactions.

If you are performing many Golden Gate assemblies with the same set of parts, it may help to make dilute stocks of identical molarity in advance.

\section{Note - This master mix needs to be prepared on ice and kept on ice!}

Taking into consideration the volume for the insert and vector DNA, prepare the following Golden Gate master mix for a final reaction volume of $\triangle 10 \mu \mathrm{L}$. Prepare the master mix according to the table below in a $1.5 \mathrm{ml}$ eppendorf tube.

- Scale up the mix below based on the number of assemblies you would like to set up.

- e.g. if the total volume of insert and vector DNA is $3 \mu \mathrm{l}$, prepare a master mix with a volume of $5.45 \mu$ of water. 


\begin{tabular}{|l|l|}
\hline A & B \\
\hline Reagents & For 1 reaction $(\mu \mathrm{l})$ \\
\hline 10x T4 Buffer & 1 \\
\hline $\begin{array}{l}\text { T4 DNA } \\
\text { Ligase } \\
(2,000,000 \\
\text { U/mL })\end{array}$ & 0.05 \\
\hline $\begin{array}{l}\text { Esp31 or } \\
\text { Bsa1v2-HF }\end{array}$ & 0.5 \\
\hline Water & To a total volume of $10 \mu \mathrm{\mu l}$ \\
\hline
\end{tabular}

Note

Tips and Tricks for the Ligase -

- Take note of the number of units of T4 DNA ligase you are using! This protocol is for $2,000,000 \mathrm{U} / \mathrm{ml}$. For T4 DNA ligase with a concentration of $400,000 \mathrm{U} / \mathrm{ml}$, use

\section{$\triangle 0.25 \mu \mathrm{L}$}

- T7 DNA ligase also works

3 Label PCR tubes (both on the side and on the lid) then place the tube on a PCR tube rack on ice.

\section{$4 \quad$ Note - This step needs to be carried out on ice!}

Aliquot the Golden Gate assembly master mix into each well on a PCR tube strip

\section{$5 \quad$ Note - This step needs to be carried out on ice!}

Add the appropriate volume of vector DNA to the master mix, as calculated in step 1.

\section{$6 \quad$ Note - This step needs to be carried out on ice!}


Add the appropriate volume of insert DNA to the master mix, as calculated in step 1. The total reaction volume should be $\triangle 10 \mu \mathrm{L}$

7 Mix the reaction by flicking the tubes and briefly spin on a PCR tube spinner. Transfer tubes back on ice.

8 Set up the following Golden Gate assembly program on a thermocycler:

\begin{tabular}{|l|l|l|l|}
\hline A & B & C & D \\
\hline Step 1 & $37^{\circ} \mathrm{C}$ & 5 minutes & \\
\hline Step 2 & $37^{\circ} \mathrm{C}$ & 5 minutes & $30 \mathrm{x}$ \\
\hline Step 3 & $16^{\circ} \mathrm{C}$ & 10 minutes & \\
\hline Step 4 & $16^{\circ} \mathrm{C}$ & 30 minutes & \\
\hline Step 5 & $37^{\circ} \mathrm{C}$ & 60 minutes & \\
\hline Step 6 & $50^{\circ} \mathrm{C}$ & 5 minutes & \\
\hline Step 7 & $80^{\circ} \mathrm{C}$ & 10 minutes & \\
\hline Step 8 & $4{ }^{\circ} \mathrm{C}$ & $\infty$ & \\
\hline
\end{tabular}


Note

Tips and Tricks for the Golden gate program -

There are shorter Golden gate assembly programs (From Martella et al. 2017)

Step $137^{\circ} \mathrm{C} 5$ minutes

Step $237^{\circ} \mathrm{C} 5$ minutes

Step $316^{\circ} \mathrm{C} 10$ minutes

repeat step 2 and 3 for another $19 x$

Step $416^{\circ} \mathrm{C} 20$ minutes

Step $537^{\circ} \mathrm{C} 30$ minutes

Step $675^{\circ} \mathrm{C} 6$ minutes

Step $74^{\circ} \mathrm{C} \quad \infty$

An alternative short program (From

https://international.neb.com/protocols/2018/10/02/golden-gate-assembly-protocol-forusing-neb-golden-gate-assembly-mix-e1601)

Step $137^{\circ} \mathrm{C} 5$ minutes

Step $216^{\circ} \mathrm{C} 5$ minutes

repeat step 1 and 2 for another $29 x$

Step $360^{\circ} \mathrm{C} 5$ minutes

Step $44^{\circ} \mathrm{C} \quad \infty$

9 Transfer PCR tubes to the thermocycler and start the program.

10 An optional step if your end-resulting plasmid does not have internal Bsal/Esp31 sites within the insert or backbone vector (other than the ones used for the assembly of insert and vector), you can add ATP-dependent DNase (Lucigen E3101K - Plasmid-Safe ${ }^{\text {TM }}$ ATP-Dependent DNase) which digests linear DNA but not circular DNA. Add $\triangle 0.25 \mu \mathrm{L}$ of Plasmidsafe DNase and

\ $0.5 \mu \mathrm{L}$ of $25 \mathrm{mM} \mathrm{ATP}$ to the Golden Gate reaction and incubate at $8^{\circ} 37^{\circ} \mathrm{C}$ for (3) 00:15:00

11 Transform the Golden Gate reaction into E. coli cells (e.g. DH5a, Mach1, TOP10, NEB10ß), following an appropriate protocol. 
